\title{
Fractal Analysis of Wavy Pattern of Frictional Coefficient of Fabrics
}

\author{
Hiroyuki Fujita*, Kazuhiko Komurasaki* \\ Takashi Matsuoka** and Kazuhiko Sakaguchi*** \\ ${ }^{*}$ Hyogo Prefectural Institute of Industrial Research, Uenodan, Nomura-cho, Nishiwaki, 677-0054, Japan \\ **Faculy of Engineering, Doshisha University, Miyakodani, Tatara, Kyotanabe, Kyoto, 610-0321 Japan
}

\begin{abstract}
Frequency analysis for a change in frictional coefficient is an important method to elucidate the complicated frictional characteristics of fabrics. The wavy patterns of frictional coefficient have the regular or irregular structure. From the viewpoint of application to the hand value and identification of fabrics, it is also expected to quantitatively evaluate the frequency distribution of wavy patterns of frictional coefficient. A method is proposed, therefore, to evaluate the frequency distribution by using fractal dimension, and the validity of this method is estimated. The results obtained are as follows :

(1) There is no correlation among the fractal dimensions, MMD and the density of fabrics.

(2) The frequency distribution of the fabrics composed of staple fiber was different from that of the fabrics made of filament fibers. The fractal property appeared on the wavy patterns of fabrics composed of staple fiber, but the fractal property did not appear on the other case.

(3) It became clear that the fractal dimensions and the correlation coefficient gave useful information as an evaluation indicator of the hand value in the fabric classification, even if fabrics were not able to be classified by only MMD and MIU obtained from the KES.

(4) The wavy patterns of the frictional coefficient of fabrics showed a class structure. As a result of simulation on the wavy patterns used the inverse Fourier transform, which was considered the class structure, the simulated wavy patterns on fabrics composed of staple fiber were similar to the experimental results.
\end{abstract}

Key Words: Wavy Pattern of Frictional Coefficient of Fabrics, Fractal Analysis, Frequency Distribution, Inverse Fourier Transform

(Received Sept. 3, 1998)

(Accepted for Publication Sept. 25, 1999)

\section{布の摩擦係数波形のフラクタル解析}

藤田 浩行*, 小紫 和彦*, 松岡 敬**, 坂口 一彦***

\section{1. 緒 言}

布の摩擦特性は, 布の手触り感覚である風合い值 に影響を与え, 風合い計測に多く用いられている KESにおいては, 平均摩擦係数 (MIU) および平均 偏差 (MMD) が測定されている1).これらの摩擦特
性は, 布の構造形態や摩擦条件（摩擦速度, 荷重お よび摩擦子の形状など）などにより変化する2).し かし, MIU, MMD は, 摩擦係数の波形に含まれた 情報を平均化して求めた值であるため, 広がりを持 つ布としての空間的な情報量としては不十分であ る.さらに, 波形の変化は, 布の規則性とランダム

*会員, 兵庫県立工業技術センター, 西脇市野村町上/段 1790-496, TEL. 0795-22-2041, FAX. 0795-22-3671

$* *$ 非会員, $* * *$ 会員, 同志社大学工学部機械系学科, 京田辺市多々羅都谷 1-3 
性を含んだ構造に起因すると考えられることから， 摩擦係数の波形に関して周波数解析を行うことは重 要である. 周波数解析に関しては, 布の構造的な要 素と測定条件などと波形に含まれる成分について解 析を行った報告がある．鋤柄らは，皮膚がちりめん に触れたときに感じる凹凸感は, 織構造の規則正し さよりあ突出したうねにより強く感じられ，それ は, 摩擦係数の波形から得られたパワースペクトル により明らかになったと報告している33. また，木 下らは, 新合瀻布の摩擦係数の波形のパワースペク トルについて, 布の表面構造および摩擦子の形状な どから検討を行っている4). これらの報告から，そ の波形には, 系の密度に対応する周波数成分や摩擦 子の形状に対応した成分などの周波数成分が含まれ ていることがわかる. しかし, それらの評価は, 定 性的なむのにとどまっている. 風合いにおける評価 值としての応用や試料の同定などの観点から, 新た な定量的評価手法が望まれる. 近年, フラクタルの 概念は, 複雑さの程度を示す指標として様々な分野 において利用されている.

そこで, 本報告では, 摩擦係数の波形についてフ ラクタル解析を行い, フラクタル次元により, 波形 の周波数成分の分布を定量化することを提案し, 波 形のフラクタル性やフラクタル次元と波形の視覚的 な複雑さなどとの関係について検討した。 また，逆 フーリエ変換を利用して, フラクタル解析結果を基 に波形の生成シミュレーションを行い, 実験波形と 比較検討することで, 布の摩擦係数波形の特徵につ いても考察を行ったので報告する.

\section{2. 実験方法}

実験に用いた布試料は，染色堅ろう度試験用添付 白布 (JISL0803) の毛, 絹, 綿, レーヨン, ナイロ ン, ポリエステルおよびアクリルの 7 種類の平織物 である. 毛, 綿およびアクリルの 3 種類は, 短繊維 による紡績系で構成されており，その他は，長緘維 の糸で構成されている.

摩擦試験は, 自動表面試験機 KES-FB4AU（カト 一テック製) を用いて, 摩擦速度 $1 \mathrm{~mm} / \mathrm{sec}$, 荷重は 摩擦子を含めて $50 \mathrm{gf}$ の条件で, $20^{\circ} \mathrm{C}, 65 \% \mathrm{RH}$ の環 境下で行った。摩擦子は, ピアノ線を10本並べた標 準仕様のあので, 形状は, $5 \mathrm{~mm}$ 角の正方形である. 摩擦係数は, A/D 変換器 (12 ビット) を利用して, アナログ信号をデジタル化してコンピュータに入力 した. データのサンプリング間隔は, $10 \mathrm{msec}(100$
$\mathrm{Hz}$ ) で, 2048個のデータを入力したため, 試料上, $20.48 \mathrm{~mm}$ の範囲を測定したことになる. 摩擦試験 は, 各試料のたておよびよこ系方向について, 各々 3 か所の測定を行った.

なお，本試験機はローカットフィルターを通して MMD を求めるが, 本報告ではフィルターは通さず に算出した.

\section{3. フラクタル解析方法}

波形のフラクタル次元を求める方法には, その波 形を正方形などの有限の大きさを持つ小領域で被覆 して, 波形を含む小領域の総数と小領域のサイズと の関係から求める Box-counting 法5)や波形のパワ ースペクトル密度関数を求め, その周波数とパワー スペクトルの関係から求める方法6) (以降, スペク トル法と呼ぶ）などがある. Box-counting 法は, 機械加工面の表面粗さや破断面などの形状の定量的 評価手法として用いられいる ${ }^{7,8}$. しかし, 摩擦係数 の波形は, 粗さ曲線のように, 縦・横軸の単位が同 一でないため, Box-counting 法を適用するのは好 ましくない，スペクトル法は，波形の周波数分布か らフラクタル次元を求める手法であり, 機械加工面 の表面粗さについて解析した報告がある ${ }^{9,12)}$. スペ クトル法では, 以下の方法でフラクタル次元を算出 できる.

周波数 $f$ とパワースペクトル $S(f)$ が，(1)式のよ うな関係にあるとき，

$$
S(f)=f^{-\beta}
$$

その波形はフラクタル性を有しているといい, べき 指数 $\beta$ からフラクタル次元 $D$ を(2)式から求めるこ とができる10).

$$
\begin{array}{ll}
D=2 & (0 \leqq \beta<1) \\
D=1+(3-\beta) / 2 & (1 \leqq \beta \leqq 3) \\
D=1(3<\beta) &
\end{array}
$$

そこで, 本研究においては, スペクトル法を用い ることとした。

なお, フラクタル次元の算出において, 自然界の 諸形状, 諸現象は, 完全なフラクタル性を有するあ のは存在しないから，その周波数 $f$ と $S(f)$ を両対 数座標上にプロットし, 最小二乗法により, 直線近 似したときの傾きを一 $\beta$ ((3)式) とすることで, フラ クタル次元を求めた． $C$ は, 定数である.このフラ クタル次元により, 周波数分布の定量化が可能であ る.

$$
\log S(f)=-\beta \log (f)+C
$$


また, 波形のフラクタル性は, 直線の近似性つま り, $\log (f)$ と $\log S(f)$ の相関係数により評価が可能 であると考えられる。

\section{4. 結果および考察}

\section{1 パワースペクトル}

摩擦係数の波形とそのパワースペクトル密度関数 の代表例としてアクリルおよびナイロンをたて糸方 向に摩擦したときの結果を図 1 および図 2 に示す.

図 1 の横軸は摩擦子の移動距離, 縦軸は摩擦係数, 図 2 の横軸は単位長さ $(1 \mathrm{~cm}$ ) 当たりの波数（周波 数), 縦軸はパワースペクトルを意味する. アクリル の波形には, パワーの大きい周波数成分が複数含ま れており,よこ糸密度 $(27.8$ 本 $/ \mathrm{cm})$ および摩擦子 のピアノ線に対応した成分 $(20.0$ 本 $/ \mathrm{cm})$ 以外にも 複数の周波数成分が含まれているのがわかる. 一 方, ナイロンの波形に含まれている周波数成分は, 主に大きな成分が 1 つだけ含まれており，これは， よこ糸密度 $(30.0$ 本 $/ \mathrm{cm})$ にほぼ対応した成分であ る. よこ糸方向に摩擦したときの波形のパワースペ
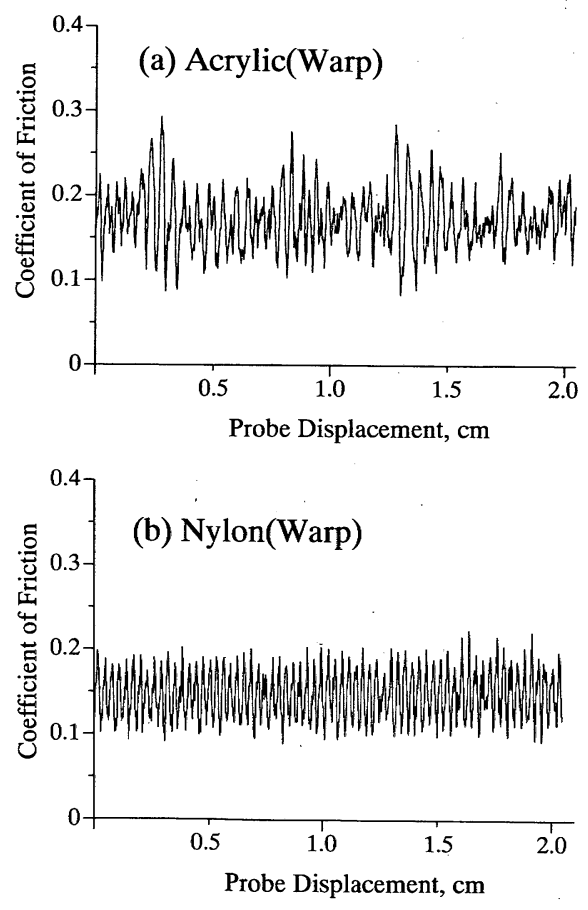

Fig. 1 The frictional coefficient of fabrics measured by thbe KES (a) Acrylic (Warp), (b) Nylon (Warp)
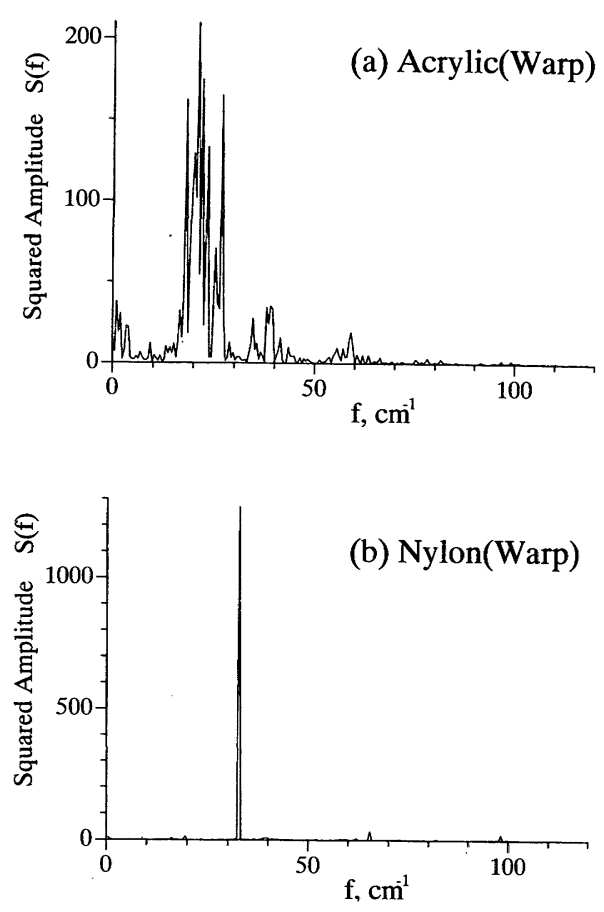

Fig. 2 Power spectra of the frictional coefficient (a)Acrylic (Warp), (b)Nylon (Warp)

クトルむたて糸方向と同様な傾向を示した.

毛および綿の波形はアクリルと同様に，パワーの 大きな周波数成分を複数含んだパワースペクトルと なり, 絹, レーヨンおよびポリエステルの波形はナ イロンと同じように織密度に対応した周波数成分が 極端に大きくなる分布を示した. この差の要因とし て, 構成する糸が前者が短繊維, 後者は長繊維であ ることから, 繊維長の差による糸表面の毛羽の挙動 の違いなどのランダム性に起因したものと考えられ る.

\section{2 フラクタル解析}

図 3 に, 図 2 の横軸および縦軸の両対数を取り, プロットした図を示す. 図3(a)のパワースペクトル は, 横軸が1.2付近を境界として, パワーの傾きが異 なり，領域 I および領域 II 分類できる。 また，図 3(b)のパワースペクトルは図3(a)のように明確では ないが, 横軸が $1.7 〜 1.8$ 付近を境界として 2 つの領 域 I とIに分類が可能である。つまり，これらの波 形のパワースペクトル密度関数は, ある值を境界と して, (1)式の $\beta$ が異なる階層的な構造を有している と考えられ，フラクタル解析を行うには，この $2 つ$ 


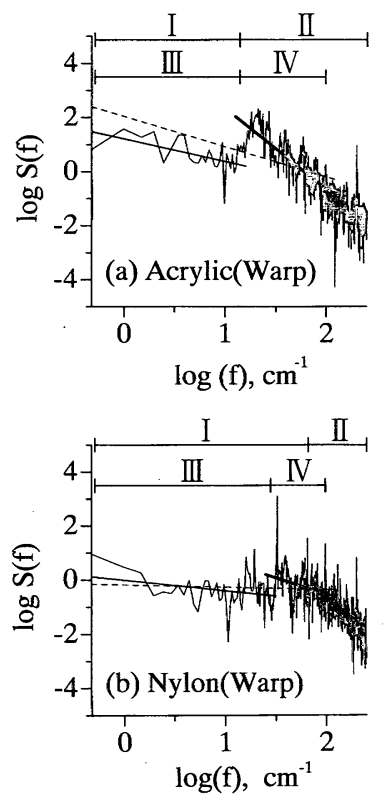

Fig. 3 The logarithm of power spectra (a) Acrylic (Warp), (b) Nylon (Warp)

の領域を各々直線近似することにより行う必要があ ると考えられる。

一方, パワースペクトルは高周波数になるほど不 安定となる傾向がある. また, 高周波数領域での計 測機の応答性の点などを考慮すれば, 高周波数の成 分ほどノイズが多く含まれていると考えられる.

そこで，計測におけるノイズ成分について検討を 行うこととした. 自動表面試験機における摩擦力の 測定は, 摩擦子に加わる接線力を差動トランスによ り検出している.ノイズの測定は，この摩擦子を外 した状態で計測機を作動させ, その状態における摩 擦力に相当する出力電圧を計測することにより行っ た. 得られた出力電圧を摩擦係数に相当する值に換 算し，そのパワースペクトル密度関数を図 4 に示 す. パワースペクトルは, 横軸が 1 以上の領域では, 約ー3を中心とした值で変動するとともに, 2.3 付近 に特に大きなパワーを持つ分布を示している. 図 4 と図 3 を対比すると, 横軸が 2 よりあ小さい領域で はノイズのパワーは摩擦係数のパワーの 100 分の 1 以下と小さくなっており, 摩擦係数波形に含まれる ノイズ成分は少ないと考えられる. しかし, 横軸が 2 よりも大きな領域では, 波長が短くなるほど摩擦 係数波形のパワーが低下することから，パワーの差 は小さくなり, 2.5付近ではノイズのパワーは摩擦

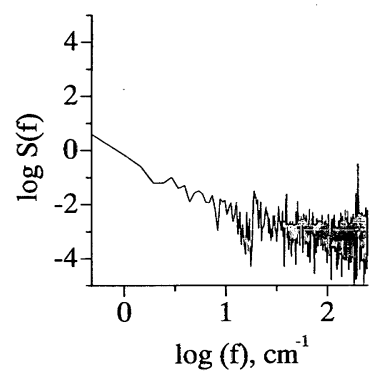

Fig. 4 The logarithm of power spectrum of wavy pattern for the noise

係数波形の 10 分の 1 ぐらいの大きさである. また, 横軸が2.3付近にノイズと考えられる大きなパワー が摩擦係数波形にも含まれるのが確認できる. 以上 の結果から, フラクタル解析を行う周波数領域の上 限を $2.0\left(\mathrm{f}=100 \mathrm{~cm}^{-1}\right)$ とすることとした. 摩擦係数 波形は図 2 で示したように, 織密度に相当する周波 数付近にパワーが極めて大きな成分を含み, その周 波数以上ではパワーが大きく低下する傾向を示す. また，波形には布のしわや厚さむらなどによる波形 のうねり成分も含まれ，その波長は数分の $1 \mathrm{~mm}$ か ら $10 \mathrm{~mm}$ 程度であると考えられる. したがって, 摩 擦係数波形の構造に関する成分は, 織密度に相当す る波長付近から, 上限值と決定した波長が $0.1 \mathrm{~mm}$ くらいまでに主に含まれていると考えられ，この波 長領域でフラクタル解析を行うこととした。 つま り, 図 3 における領域IVがフラクタル解析を行う波 長領域である.なお，パワースペクトルは，波形の 特徴を明確にするため, 平滑化は行っていない.

図3(a)のスペクトルでは，よこ糸の織密度に相当 する波長付近の值を境界値として 2 つの領域 I と II に分類できる. 領域 I は布のしわや厚さむらなどに よる波形のうねり成分を含む周波数領域であり，領 域 II は高い周波数領域でノイズ成分を多く含んでい る. 領域 I と II の境界値はフラクタル解析を行う領 域IVの低い周波数側の値と一致し，これはその他の 短繊維試料であ同様であった. 一方, 図 3(b)のスペ クトルの領域 I と II の境界值は, よこ糸の織密度に 相当する周波数よりかなり大きい值を示したが，こ の値はノイズ成分に大きく影響されていると考えら れる.つまり, 領域Iにおいて直線近似して求めた フラクタル次元は, 波形の主要な波長成分を解析し たあのでないこととノイズを多く含んだ領域での解 析であるため, 数値の信頼性は低いと思われる.こ 
れは，その他の長繊維試料についてあ同様なことが いえる. 図3(a)，(b)の領域IVを近似した直線を太い 実線で示す．この直線の傾きが，(3)式の $\beta$ に相当す る. すべての波形についてフラクタル解析を行い, 波形のフラクタル性およびフラクタル次元の定量的 な評価値としての有効性などについて以下のとおり 検討する.

表 1 に, 各試料のフラクタル次元, 近似直線の傾 き $\beta$, 近似直線の相関係数および MMD の平均值を 摩擦方向ごとに示す. 短繊維試料の近似直線の相関 係数は, 0.662 以上と長繊維試料と比較して大きな 値を示し, 領域IVでのスペクトルはフラクタル性を 有すると考えられる. 一方, 長繊維試料の相関係数 は, $0.230 \sim 0.557$ と短繊維に比べると小さな值を示 し，これらの波形のスペクトルはフラクタルでない と考えられるが，レーヨンは比較的大きな值を示し た. また，近似直線の傾きが 3 以上となり，フラク タル次元が 1 となった試料がいくつかあった。この 傾きは, フラクタル次元とは負の比例関係にあるこ とから, スペクトルの特徴量として利用でき, 波形 の詳細な解析においては重要な值になると考えられ る.

近似直線の傾き $\beta$ と相関係数の関係を図 5 に示 す.黒く塗りつぶされた印は短繊維, 白抜きおよび ×印は長纎維による試料である，前述したとおり， 短繊維および長繊維の試料間で明らかに相関係数が 異なるのがわかる，長瀻維の波形の特徴は，図 2(b)
のような極めて大きなパワーを持つ成分およびその 周波数の $0.5,2,3, \cdots$ 倍の周波数以外にはパワー をほとんど有しないような高い周期性を表すパワー スペクトルとなる．したがって，図3(b)は，それらの 周波数に対応したパワーが, 極端に大きな值を示し ながら変動しており, そのために, 相関係数は小さ くなる傾向を示したと考えられる。，一方，短織維の パワースペクトルには, 織密度に対応した周波数成 分以外にあパワーの大きな周波数成分を複数含むこ とから, 図3(a)のとおり, 顕著に振動する周波数成 分は少ない分布を示したため, 相関係数は大きくな ったと考えられる.このように短繊維および長緎維 の試料間で相関係数が異なったのは, 構成する系の 繊維長による織物表面の繊維の挙動が, 波形の周期 性に影響を与えたためと考えられる. また，短緎維 および長緘維の試料内で近似直線の傾き之相関係数 には比例関係が見られた。

図 5 のとおり長繊維試料の相関係数は短繊維試料 に比べて小さな值を示したが, その值は広い範囲に 分布している. 相関係数は, 波形の周期性により変 化すると考えられ, 相関係数が異なれば, 視覚的に 波形が異なることが予想される. そこで, 相関係数 が大きな值 (0.536) を示したナイロン（よこ）(図 5 参照) のスペクトルと小さな値 $(0.196)$ を示した 絹（たて）(図 5 参照) のスペクトルを図 6 に示す. 相関係数の小さな絹のスペクトルはナイロンと比較 して, 解析領域内においてパワースペクトルが非常

Table 1 Fractal analysis of wavy pattern of the frictional coefficient of fabrics

\begin{tabular}{|c|c|c|c|c|c|c|c|c|}
\hline & & Wool & Silk & Cotton & Polyester & Acrylic & Nylon & Rayon \\
\hline \multirow{3}{*}{$\begin{array}{c}\mathrm{W} \\
\mathrm{a} \\
\mathrm{r} \\
\mathrm{p}\end{array}$} & $\begin{array}{c}\text { Fractal Dimension } \\
\text { ( Slope } \beta)\end{array}$ & $\begin{array}{l}1.208 \\
(2.585)\end{array}$ & $\begin{array}{l}1.912 \\
(1.177)\end{array}$ & $\begin{array}{l}1.036 \\
(2.929)\end{array}$ & $\begin{array}{l}1.841 \\
(1.319)\end{array}$ & $\begin{array}{l}1.078 \\
(2.844)\end{array}$ & $\begin{array}{l}1.744 \\
(1.512)\end{array}$ & $\begin{array}{l}1.409 \\
(2.183)\end{array}$ \\
\hline & Coefficient of Correlation & 0.662 & 0.230 & 0.663 & 0.250 & 0.711 & 0.292 & 0.557 \\
\hline & MMD & 0.0195 & 0.0478 & 0.0265 & 0.0216 & 0.0228 & 0.0239 & 0.0189 \\
\hline \multirow{3}{*}{$\begin{array}{c}\mathrm{W} \\
\mathrm{e} \\
\mathrm{f}\end{array}$} & $\begin{array}{c}\text { Fractal Dimension } \\
\text { (Slope } \beta)\end{array}$ & $\begin{array}{l}1.000 \\
(3.315)\end{array}$ & $\begin{array}{l}1.854 \\
(1.292)\end{array}$ & $\begin{array}{l}1.000 \\
(3.723)\end{array}$ & $\begin{array}{l}1.573 \\
(1.854)\end{array}$ & $\begin{array}{l}1.000 \\
(3.205)\end{array}$ & $\begin{array}{l}1.000 \\
(3.143)\end{array}$ & $\begin{array}{l}1.224 \\
(2.552)\end{array}$ \\
\hline & Coefficient of Correlation & 0.781 & 0.363 & 0.790 & 0.338 & 0.729 & 0.469 & 0.466 \\
\hline & MMD & 0.0222 & 0.0114 & 0.0321 & 0.0272 & 0.0299 & 0.0157 & 0.0405 \\
\hline
\end{tabular}




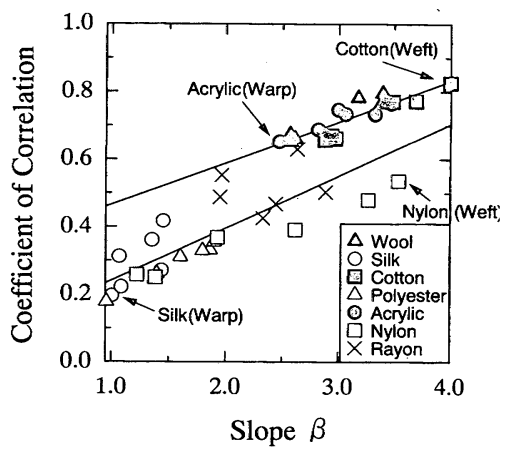

Fig. 5 Relation between slopes of the line fitted power spectrum and correlation coefficient between the frequency and power spectrum
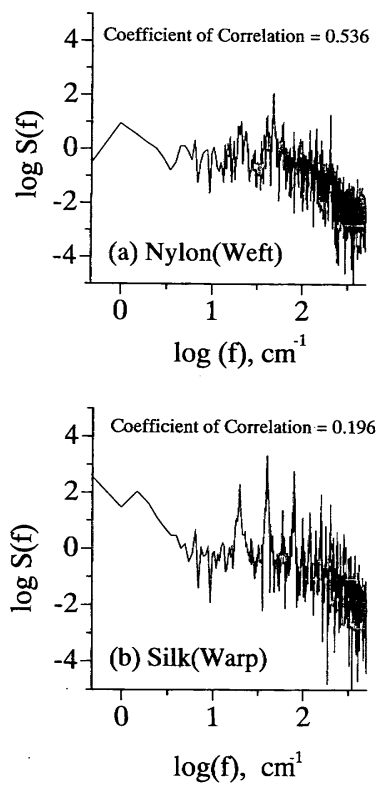

Fig. 6 Comparison of the logarithm of power spectra for the wavy patterns

(a) Nylon (Weft), (b) Silk (Warp)

に激しく変動しており，そのため相関係数は小さな 值を示した。両者の摩擦係数波形を図 7 に示す. 視 覚的に比較しやすいよう, 縦軸の尺度を変化させて 表示している. 絹の波形はナイロンと比べて，その 振幅は比較的安定し, 規則正しい变動を繰り返して いる．つまり，高い周期性を有する波形ほど，相関 係数は小さくなると考えられ，短繊維と長繊維の試 料間の相関係数の違いの要因と同様であった.

フラクタル性を示す場合, フラクタル次元は波形
の複雑さの程度を示す指標となる．そこで，フラク タル次元が小さな值 (1.000) を示した綿（よこ）(図 5 参照）と大きな值（1.264）を示したアクリル（た て）（図 5 参照）の波形を図 8 に示す.アクリルの波 形は綿と比べて視覚的な複雑さの度合いが大きい。 フラクタル次元は大きいほど複雑さの度合いは増大 するが，アクリルのフラクタル次元の方が大きくな

(a) Nylon(Weft)

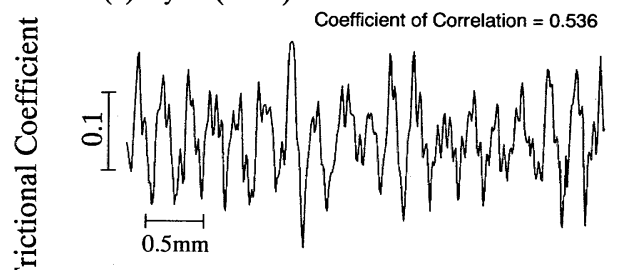

(b) Silk(Warp)

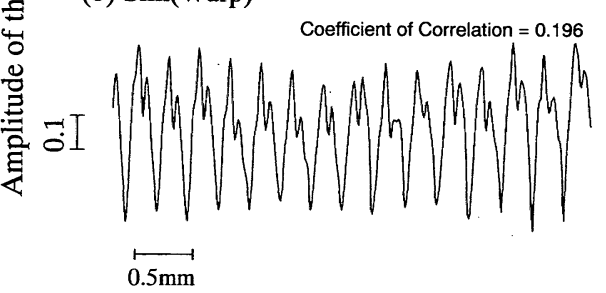

Probe Displacement

Fig. 7 Comparison of the visual feature of the wavy patterns for the frictional coefficient (a) Nylon (Weft), (b) Silk (Warp)

(a) Cotton(Weft) Fractal Dimension $=1.000$
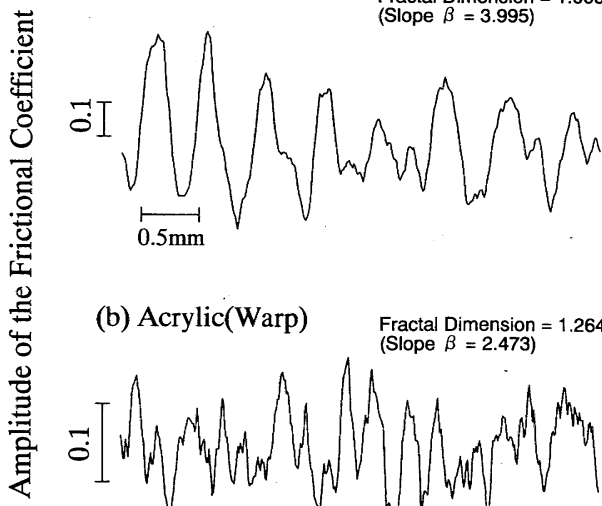

(b) Acrylic(Warp) Fractal Dimension $=1.264$

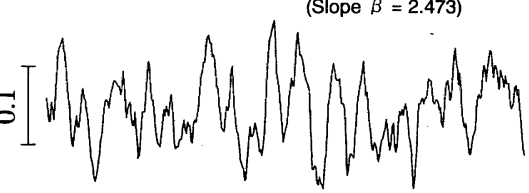

$0.5 \mathrm{~mm}$

\section{Probe Displacement}

Fig. 8 Comparison of the visual feature of the wavy patterns for the frictional coefficient (a) Cotton (Weft), (b) Acrylic (Warp) 
ったことは，視覚的な複雑さ度合いと一致したこと になる。

図 9 にフラクタル次元と MMD の関係を示す.そ の結果，両者には相関関係は見られなかった。これ は, MMD が波形の振幅により変化する特徴量で, 平均値からのばらつきの程度を示す值であるためで ある.つまり，フラクタル次元は(3)式のとおり，周 波数とパワースペクトルの相対的な関係から求める あのであるから，MMD とは異なった波形の特徵を 表していると考えられる。

フラクタル次元と織密度の関係について検討す る. 摩擦子の形状から, たて糸方向の摩擦はよこ系 密度に, よこ糸方向の摩擦はたて糸密度に影響され る2). そこで，たて糸方向に摩擦した試料はよこ系 密度を，よこ糸方向に摩擦した試料はたて糸密度を 縦軸にし，フラクタル次元との関係を示したのが図 10である. その結果, 両者には相関関係は見られな かった.

以上の結果から，フラクタル性の程度を示す相関

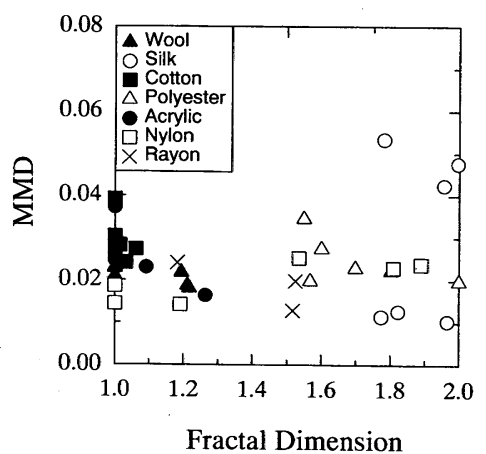

Fig. 9 Relation between fractal dimensions and MMD

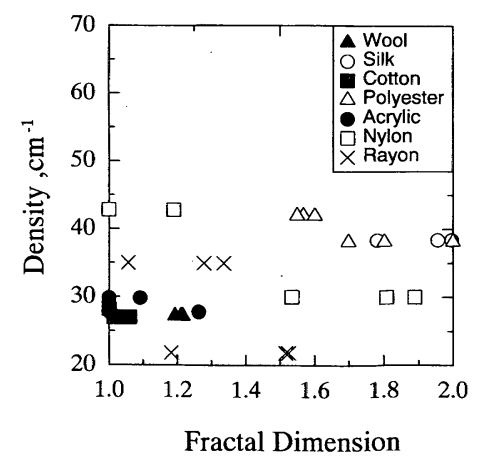

Fig. 10 Relation between fractal dimensions and density of fabrics
係数およびフラクタル次元は, 摩擦係数波形の特徴 を定量化した評価値として有効であることが確認で きた.これらは, MIUや MMD とは全く異なった評 価値であることからす, 試料の分類や同定などに役 立つと考えられる.また, 短繊維と長繊維の試料間 で相関係数が異なる傾向を示したことなどからあ, 触感の新たな評価值としての可能性ああり，これに ついては官能検查などを行うことなどによる有効性 の検討が必要である.さらに, 織物の摩擦係数波形 は, 織組織や系の太さなどの構造的な特徵に影響を 受けて変化すると考えられことから, 構造的な特徵 とフラクタル次元などとの関係について検討するこ とあ今後の課題である.

\section{3 摩擦係数波形の生成シミュレーション}

4.2 では摩擦係数波形のフラクタル性やフラクタ ル次元について検討し，短瀻維試料と長緎維試料間 においてフラクタル性の指標である相関係数が異な る傾向を示すことがわかった．また，フラクタル性 を有すると考えられる短繊維試料の摩擦係数波形の パワースペクトル密度関数は, 低周波数領域（領域 I）および高周波数領域（領域 II）の 2 つのエリア に分割することが可能であり，階層構造を有してい ると考えられた。

そこで, 短織維試料および長繊維試料のフラク夕 ル性やパワースペクトルの階層的な構造が波形の特 徵によ゙のように影響を与えるか検討するために， フ ラクタル解析結果から摩擦係数波形を生成させるシ ミュレーションを行った。

波形は, 実験波形のフラクタル次元を基に, 逆フ ーリエ変換を利用して生成シミュレーションを行 い, 実際の波形との比較・検討を行った. シミュレ ーション方法について以下に述べる.

不規則変動を表すモデルとして, 非整数ブラウン 運動 $B_{H}(t)$ がある. 本シミュレーションでは, 非整 数ブラウン運動を用いて不規則変動曲線を発生させ た.これは, 変数を $t$ とし, $0<H<1$ の值をとるパ ラメータ $H$ によって特徵づけられ, 正の任意のス ケール $a$ に対して(4)式が成り立つあのである ${ }^{11)}$.

$$
\begin{aligned}
& B_{H}(t+\tau)-B_{H}(t) \\
& =a-H\left\{B_{H}(t+a t)-B_{H}(t)\right\}
\end{aligned}
$$

なお，フラクタル次元 $D$ は，パラメータ $H$ と(5) 式の関係がある.

$$
D=2-H
$$

この $B_{H}(t)$ は, 係数 $C a$ を用いて, (6)式のように, 
逆フーリエ変換により表すことができる ${ }^{12)}$. なお, $f$ は周波数である.

$$
B_{H}(t)=\int C a \exp (j 2 \pi f t) d f \quad j=\sqrt{-1}
$$

(6)式の係数 $\mathrm{Ca}$ には, 波形の振幅の大きさに対応 する項 $k, \beta$ のべき乗で減衰する項 $f^{-\beta}$, そして不規 則性を導入するために乱数である $r$ を導入した。

$$
C a=k f^{-\beta} \exp (j 2 \pi r)
$$

なお, 乱数 $r$ は， $0 \sim 1$ の範囲の一様乱数とした。 以上の方法で，不規則変動曲線を発生させた。

シミュレーションの対象とした波形は, アクリル とナイロンをたて糸方向に摩擦した図 1 に示す $2 つ$ の波形とした. シミュレーションでは, 布の摩擦係 数波形の特徵について検討を行うため, 階層構造を 考慮しないシミュレーションと階層構造を考慮した シミュレーションの 2 種類について行った. 階層構 造を考慮したシミュレーションのフラクタル次元 は, 波形のうねり成分に相当する波長領域 (領域吕) とフラクタル解析を行った領域IVを直線近似するこ とで求めたフラクタル次元を用いた. なお，領域IV よりも波長の短い領域については, 領域IVを近似し た直線の傾きでパワースペクトルが分布するとし た. 各領域を近似した直線を図 3 に実線で示す。ま た，階層構造を考慮しない場合は，領域正およびIV の 2 つの領域を近似した点線の直線（図 3 参照）の 傾きから求めたフラクタル次元を用いた。 なお，フ ラクタル次元が 2 の場合は, 各近似直線の傾き $\beta$ を 利用してシミュレーションを行った。 それらの值お よび階層構造の境界周波数は, 表 2 のよおりであ る.

図11にアクリルの波形について, 実験結果から得 られた表 2 の数値を基にシミュレーションを行った

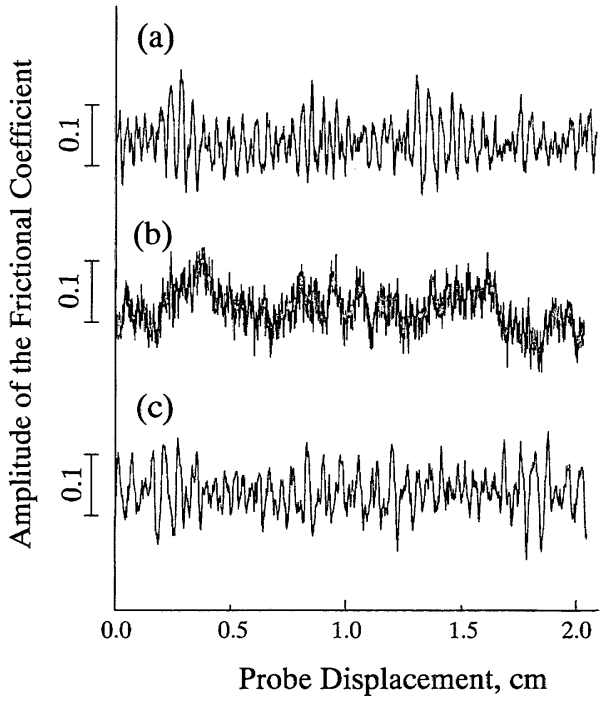

Fig. 11 Simulation of the wavy patterns of acrylic with using the inverse Fourie transform

(a) The wavy pattern obtained by the frictional experiment, (b) The wavy pattern under no consideration of the class structure, (c) The wavy pattern under consideranion of the class structure

結果を示す．上から順に実験による波形，階層構造 を考慮しないシミュレーション波形, 階層構造を考 慮したシミュレーション波形を示す. 図12には, ナ イロンのシミュレーション結果についても同様に示 す．また，それらの波形のパワースペクトルを図 13 （アクリル）および図14（ナイロン）に示す. 階層構

Table 2 Fractal dimensions for the simulation evaluated under considering the class structure

\begin{tabular}{|c|c|c|c|c|}
\hline \multirow{2}{*}{} & \multicolumn{3}{|c|}{$\begin{array}{c}\text { Fractal Dimension } \\
\text { (Slope } \beta \text { Frequency } \\
\left(\mathrm{cm}^{-1}\right)\end{array}$} \\
\cline { 2 - 4 } & III & $\mathrm{I}$ & III \& N & \\
\hline Acrylic & $\begin{array}{c}2.000 \\
(0.836)\end{array}$ & $\begin{array}{l}1.003 \\
(2.995)\end{array}$ & $\begin{array}{l}1.941 \\
(1.118)\end{array}$ & \multirow{2}{*}{13.7} \\
\hline Nylon & $\begin{array}{c}2.000 \\
(0.396)\end{array}$ & $\begin{array}{l}1.889 \\
(1.223)\end{array}$ & $\begin{array}{l}2.000 \\
(0.090)\end{array}$ & 29.3 \\
\hline
\end{tabular}




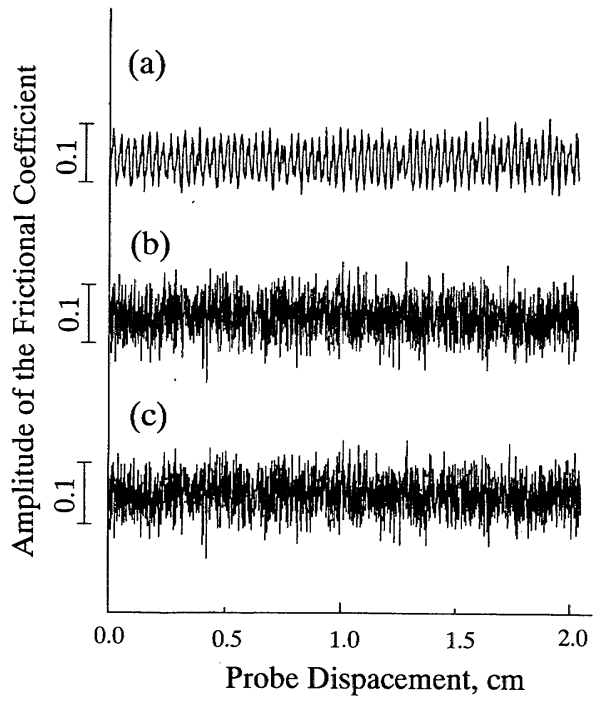

Fig. 12 Simulation of the wavy patterns of nylon with using the inverse Fourier transform (a) The wavy pattern obtained by the frictional experiment, (b) The wavy pattern under no consideration of the class structure, (c) The wavy pattern under consideration of the class structure

造を考慮しなかった場合は，アクリルおよびナイロ ンとあ実験波形とは大きく異なる波形となった。一 方, 階層構造を考慮した場合，アクリルについては 実験波形と視覚的によく似た波形を生成することが できた. しかし，ナイロンについては，実験波形に 似た波形は得られなかった。

図13，図14から階層構造を考慮せずに生成した波 形は，そのパワースペクトルに階層構造は見られな
い. 階層構造を考慮して生成させたアクリルの波形 は視覚的に実験波形とよく似た波形となったが，そ のパワースペクトルあ図13(c)のとおり階層構造を有 している．以上からも，アクリルなどの短繊維で構 成され，フラクタル性を有する波形については，階 層構造を考慮することにより視覚的に似た波形の生 成が可能である. しかし，ナイロンについては階層 構造を考慮した場合です，視覚的にかなり異なった シミュレーション波形となった。 ナイロンの実験波 形の場合，特に織密度に対応した波長に大きなパワ 一を含むスペクトル分布を示したが，シミュレーシ ヨンの場合, 織密度に対応する波長に, 極端に大き なパワーを有する成分は含まれていないことが最大 の要因と考えられる.また, 領域IVより波長の短い 領域を領域IVで近似した直線の傾きで近似し，シミ ュレーションを行ったが，この領域では，近似直線 の傾きとスペクトルの分布と大きく異なったことな どあ要因として考えられる。

シミュレーションでは，波形のパワースペクトル 密度関数がフラクタル性を有していると仮定して行 っている.つまり, 短緘維試料において, 視覚的に 似た波形を生成できたことは，そのパワースペクト ル密度関数は, 明らかにフラクタル性を有するとと あに，階層構造であることが確認できた，また，パ ワースペクトル密度関数の階層構造は, 波形の特徴 に大きな影響を与えることがわかった。

\section{5. 結 言}

布の摩擦係数波形に含まれる周波数分布をフラク タル次元により定量化することを提案し，摩擦係数 波形のフラクタル性やフラクタル次元と波形の視覚 的な複雑さなどとの関係について検討した.

その結果, 短繊維で構成される織物の波形と長繊
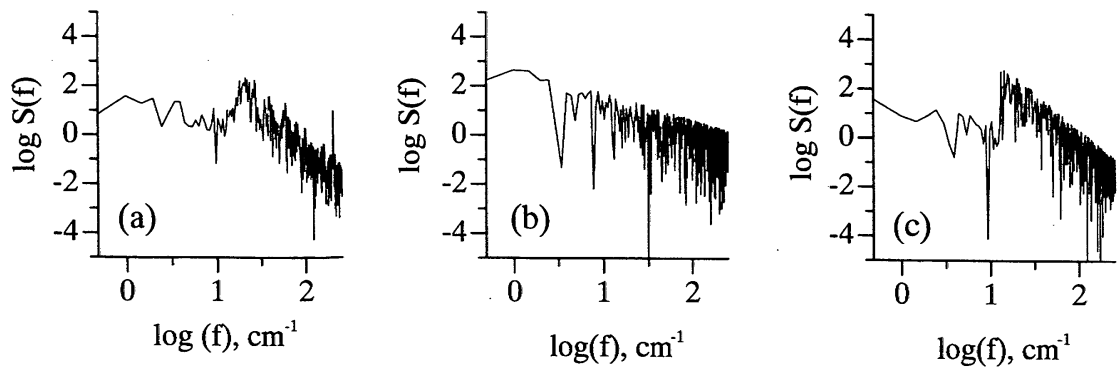

Fig. 13 The logarithm of power spectra of the wavy patterns of Fig. 11

(a) The wavy pattern obtained by the frictional experiment, (b) The wavy pattern under no consideration of the class structure, (c) The wavy pattern under consideration of the class structure 

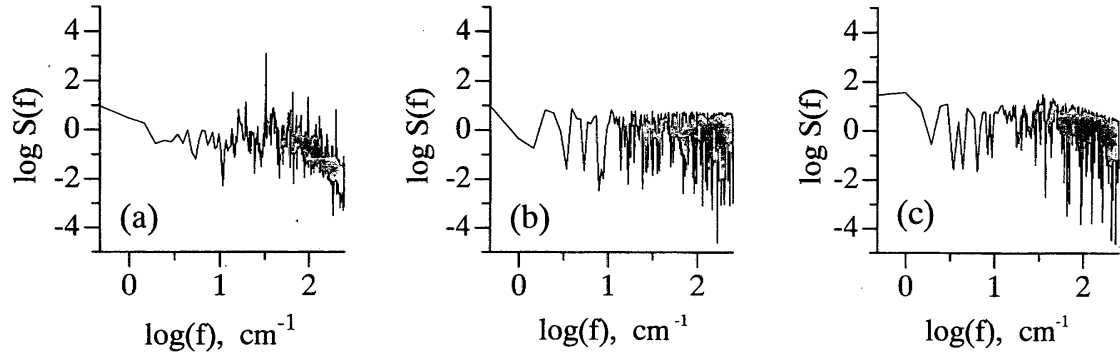

Fig. 14 The logarithm of power spectra of the wavy patterns of Fig. 12

(a) The wavy pattern obtained by the frictional experiment, (b) The wavy pattern under no consideration of the class structure, (c) The wavy pattern under consideration of the class structure

維で構成される織物の波形間では，周波数分布が異 なった，そのために，短纎維の波形はフラクタル性 を有すると考えられたが, 長絾維の波形はフラクタ ル性を示さなかった。フラクタル性を有した短繊維 の波形では, フラクタル次元が大きい波形の方が, 波形の視覚的な複雑さの程度は大きかった。 また, フラクタル次元は MMD および織密度とは相関関 係はなかった。

以上から，MIU および MMD だけでは表現でき ない摩擦係数波形の定量的評価が可能になるととも に，風合いにおける評価値および試料の同定に役立 つあのと期待できる.

実験波形のフラクタル次元から，パワースペクト ル密度関数の階層構造を考慮し, 逆フーリエ変換を 利用した波形の生成シミュレ゙ーションを行った。そ の結果, 短織維で構成される織物の波形について は, 実験結果と視覚的に良く似た波形を生成するこ とができたことから，短㵶維の波形のスペクトル は，フラクタル性を有するととあに，階層構造であ ることが確認できた。

\section{参考文献}

1) S. Kawabata ; J. Text. Mach. Soc. Japan (Japanese Ed), 33,136 (1980)

2) R. Akiyama, X. Hong, M. Kinoshita, F. Okamoto, K. Tanaka and T. Matsuo ; J. Text. Mach. Soc. Japan (Japanese Ed), 48, T153 (1995)

3) S. Sukigara and T. Ishibashi ; SEN-I GAKKAISHI, 50, 349 (1994)

4) M. Kinoshita, S. Noda, R. Akiyama and T. Matsuo ; J. Text. Mach. Soc. Japan (Japanese Ed), 50, T187 (1997)

5) H. Takayasu; JOURNAL OF JAPANESE SOCIETY OF TRIBOLOGISTS, 40, 527 (1995)

6）高安秀樹；“フラクタル”, p23, 朝倉書店（1986）

7）渋谷嘉久, 川口尊久, 鏡重次郎, 㚼沢鉄三 ; トライボロジ 一学会トライボロジー会議予稿集, 317 (1995)

8）内藤公喜,藤井透; 日本機械学会論文集（A 編）62，603, 194 (1996)

9) A. Majumdar, B. Bhushan ; Journal of Tribology, 112, 205 (1990)

10) T. Higuchi ; Physica, D, 46,254 (1990)

11）6）の文献の $\mathrm{p} 152$

12）伊藤憲朗, 塚田忠夫 ; 日本設計工学会誌, 27, No. 12,525 (1992) 